\title{
Altered Levels of Nodal Excitability by Rate-Dependent Inhibitory Effects of Essential Oil of Citrus aurantium on the Electrophysiological Properties of Isolated Perfused Rabbit AV- Node. Protective Role in the Prevention of Ouabain Toxicity
}

\author{
Alteración de los Niveles de Excitabilidad Nodal por Efectos Inhibitorios Velocidad-Dependiente del \\ Aceite Esencial de Citrus aurantium sobre las Propiedades Electrofisiológicas del Nodo AV Aislado y \\ Perfundido de Conejo. Papel Protector en la Prevención de Toxicidad por Ouabaína.
}

\author{
${ }^{*}$ Vahid Khori; ${ }^{* *}$ Mohsen Nayebpour; ${ }^{* * *}$ Azad Reza Mansourian; \\ ${ }^{* * * * *}$ Ali Davarian; ${ }^{* * * * * *}$ Mohsen Naseri; ${ }^{* * * * * *}$ Aref Salehi \& ${ }^{* * * * * * *}$ Ali-Mohamad Alizadeh
}

KHORI, V.; NAYEBPOUR, M.; MANSOURIAN, A. R.; DAVARIAN, A.; NASERI, M.; SALEHI, A. \& ALIZADEH, A-M. Altered levels of nodal excitability by rate-dependent inhibitory effects of essential oil of Citrus aurantium on the electrophysiological properties of isolated perfused rabbit AV-Node. Protective role in the prevention of Ouabain toxicity. Int. J. Morphol., 28(2):445-451, 2010.

SUMMARY: Treatment of supraventricular arrhythmia includes a wide range of medical interventions. Herbal remedies are suitable alternatives to synthetic drugs due to their availability, minimal side effects and lower price. Pharmacological studies and traditional medical literature point to the cardiovascular effects of Citrus aurantium L. (Rutaceae) in many instances. In the present study we used isolated perfused AV-node of rabbit as an experimental model to determine the effect of various concentrations of essential oil of $C$. aurantium $(0.1-0.3 \mathrm{v} / \mathrm{v})$ on the nodal conduction time and refractoriness of an isolated rabbit AV-nodal preparations. Selective stimulation protocols were used to independently quantify AV nodal recovery, facilitation and fatigue in 18 rabbits. Our results showed concentration-dependent and rate-independent suppressive effects of essence of $C$. aurantium on the Wenchebach cycle length (WBCL), AV Conduction Time (AVCT) and effective and functional refractory periods (ERP \& FRP). Functional properties such as facilitation and fatigue were significantly increased by this plant. Citrus aurantium plays a protective role against the toxic effects of ouabaine by increasing AV nodal conduction time and refractoriness. The above results indicated differential effects of $C$. aurantium on slow and fast pathways, with a dominant role on fast pathways. This research has explained the protective role of $C$. aurantium on ouabaine toxicity. All results indicated the potential anti-arrhythmic effects of $C$. aurantium in treating supraventricular tachyarrhythmia.

KEY WORDS: Citrus aurantium; Isolated AV-node; Arrhythmia; Herbal drugs.

\section{INTRODUCTION}

The drugs available for the treatment of arrythemia, due to their pro arrhythmic characteristics, constantly carry a risk of various side effects for patients (Guerra et al., 1998). Consequently, herbal remedies are suitable alternatives to drug treatment of supraventicular arrhythmia. Herbal medicine has a long history of treatment of arrhythmia. Digital has been used to treat atrial fibrillation for more than 100 years (Lewis et al., 1922). Citrius aurantium is a tree four meters tall with shiny and fragrant leaves, a bitter taste and plenty of essences (Fleming, 2001).

Folklore medicine has used different parts of $C$. aurantium to treat many types of diseases, including tachycardia, and also either as a cardiac tonic or diuretic

* Department of Pharmacology, Golestan cardiovascular research center, Golestan University of Medical Sciences, Gorgan, Iran.

** Department of Pharmacology, Faculty of Pharmacy, Tehran University of Medical Sciences, Tehran,Iran.

*** Department of Biochemistry, Faculty of medicine, Golestan University of Medical Sciences, Gorgan, Iran.

**** Department of Pharmacology, Golestan Cardiovascular Research Center, Golestan University of Medical Sciences, Gorgan, Iran.

****** Department of Pharmacology, Faculty of medicine, Shahid University of Medical Sciences, Tehran, Iran.

******* Department of Cardiology, Golestan cardiovascular research center, Golestan University of Medical Sciences, Gorgan, Iran.

******** Department of Physiology, Faculty of Medicine, Tehran University of Medical Sciences, Gorgan, Iran. 
KHORI, V.; NAYEBPOUR, M.; MANSOURIAN, A. R.; DAVARIAN, A.; NASERI, M.; SALEHI, A. \& ALIZADEH, A-M. Altered levels of nodal excitability by rate-dependent inhibitory effects of essential oil of Citrus aurantium on the electrophysiological properties of isolated perfused rabbit AV-Node. Protective role in the prevention of Ouabain toxicity. Int. J. Morphol., 28(2):445-451, 2010.

(Wu et al., 1994; Joshi, 2003). Citrius aurantium's chief constituents are volatile oils (linalool, limonene and their acetates, which are nerolidol and dimethyl antraniylate), flavonoids and frucoumarins (Fleming; Joshi).

The flavonoids have a positive inotropic effect on the heart, through an increase in cyclic adenosine monophostate (cAMP), which enhances calcium flow and, consequently, increases intracellular calcium ion concentration (Takeya et al., 1989; Shoshan \& MacLennan, 1981). The flavonoids have an inhibitory effect on the sodium-potassium pump, and are bound to an enzyme which is independent of the cardiac glycosidic site (Hirano et al., 1989; Umarova et al., 1998; Itoigawa et al., 1999).

The present study assessed the effect of various concentrations of $C$. aurantium on the basic and ratedependent behavior of AV nodal conduction time and refractoriness, and particularly their effect on AV nodes' dual pathways. The effect of essence was also assessed in the presence of ouabain to explain the role of $\mathrm{Na}+\mathrm{K}+$-ATPase in the mechanism of $C$. aurantium. The other aim of this study was to compare the relative potency of $C$. aurantium to verapamil. The results of this investigation can explain either the antiarrhythmic or arrhythmogenic effect of $C$. aurantium on the atrioventricular node.

\section{MATERIAL AND METHOD}

The essence of $C$. aurantium used in this investigation was prepared by hydrodistillation from blossoms during March-April 2000 from Gorgan, a town southeast of the Caspian Sea in the north of Iran. A voucher (3-67-1) specimen was designated by Mazandaran pharmacy college in the north of Iran. The fresh blossoms were collected, and their distillated essence was analyzed by Clavenger (G.C3800). All experiments were performed in vitro on isolated perfused rabbit cardiac preparations obtained from hearts on Newsland, from white male rabbits weighing 1$1.3 \mathrm{~kg}$. Ethical approval and animal care were in accordance with the principles in the regulations in use at the University of Golestan. Anesthesia was induced via pentobarbital $(35 \mathrm{mg} / \mathrm{kg})$ injection in an ear vein, and heparin $(200 \mathrm{IU} / \mathrm{kg})$ was used as an anticoagulant. Lateral thoracotomy was performed and the heart was excised.

Isolated AV-nodal preparation. Experiments were performed in isolated, perfused rabbit AV-nodal preparations. The preparation, perfusion system, stimulation technique and recording system were similar to those previously described in detail (Nayebpour et al., 2001). The final preparation, which included the right atrium, AV nodal area and upper part of the interventricular septum, was mounted in a tissue bath superfused at $200 \mathrm{ml} / \mathrm{min}$ with a $6-\mathrm{L}$ volume of oxygenated $\left(95 \% \mathrm{O}_{2}-5 \% \mathrm{CO}_{2}\right)$ Tyrods solution, maintained at $37^{\circ} \mathrm{C}(\mathrm{pH}=7.38)$.

The aorta was retrogradely perfused by a peristaltic pump at a constant pressure equivalent to $60-80 \mathrm{~mm} \mathrm{Hg}$. The composition of the Tyrods solution was (mmol/l): $\mathrm{NaCl}$, 128.2; $\mathrm{KCl}, 4.7 ; \mathrm{CaCl}_{2}, 2 ; \mathrm{MgCl}_{2}, 1 ; \mathrm{NaHCO}_{3}, 25 ; \mathrm{NaH}_{2} \mathrm{PO}_{4}$, 0.7 ; and dextrose, 11.1. A bipolar iridium-platinum stimulating electrode was positioned on the upper atrium near the sinus node and unipolar electrograms were recorded from near the sinus node and His bundle. Stimulation protocols were executed by custom-made software running on a Pentium computer interfaced with a D/A converter and a stimulus isolator. Electrogram signals were filtered (30 $\mathrm{HZ}$ to $3 \mathrm{KHz}$ ) and amplified by the amplifier; afterward A/D conversion data were saved on the hard disk and analyzed off-line.

Specific stimulation protocols were used to quantify the rate-dependent properties of AV nodal recovery, facilitation and fatigue, as previously described (Nayebpour et al.). To construct the basic recovery curve, a single premature or delayed stimulus (S2) was introduced after every 10 basic stimuli (S1). The relation between the conduction time of the test beat $(\mathrm{A} 2 \mathrm{H} 2)$ and the preceding recovery time (H1 A2) was established and fitted to an exponential function as previously described (Nayebpour et al.). To study facilitation, the recovery curve was constructed following a facilitation inducing a short cycle introduced after the last basic stimulus. To analyze AV nodal fatigue, two series of tachycardia with a constant AA interval were initiated, and the change in the AH interval over five minutes at a given AA interval was observed. A recovery period of at least five minutes was allowed after each tachycardia, to dissipate fatigue before the next tachycardia was initiated. The functional and effective refractory periods, and the Wenckebach, of the AV node (AVFRP and AVERP, WBCL, respectively) were measured with an extra stimulus technique, as previously described (Nayebpour et al.).

Experimental protocols. All the stimulation protocols were carried out as follow. Control conditions (no intervention) and the presence of one of three groups (A-C) of experiments:

A.- The first series of experiments studied separately and cumulatively the effects of different concentrations of $C$. aurantium essence (0.1-0.3 v/v) on the electrophysiological properties of the AV node. This set of experiments was used to determine the optimum concentration of $C$. aurantium to produce desirable responses. 
KHORI, V.; NAYEBPOUR, M.; MANSOURIAN, A. R.; DAVARIAN, A.; NASERI, M.; SALEHI, A. \& ALIZADEH, A-M. Altered levels of nodal excitability by rate-dependent inhibitory effects of essential oil of Citrus aurantium on the electrophysiological properties of isolated perfused rabbit AV-Node. Protective role in the prevention of Ouabain toxicity. Int. J. Morphol., 28(2):445-451, 2010.

B, C.- Separate series of experiments were performed to determine the involvement of $\mathrm{Na} / \mathrm{K}+$-ATPase in the essence's AV nodal effects, and to compare the relative potency of $\mathrm{C}$. aurantium to the calcium channel blocker.

The stimulation protocols were carried out during control conditions (no intervention) and with the addition of ouabain $(0.15 \mu \mathrm{M})$ after adding the essence $(0.2 \mathrm{v} / \mathrm{v})$. Verapamil $(0.1 \mu \mathrm{M})$ was used separately in the absence of essence.

The protocols were performed after a perfusion period of $20 \mathrm{~min}$ (Verapamil) and $30 \mathrm{~min}$ (ouabain). Our pilot studies showed that 45 min of perfusion with essence is enough to obtain steady state electrophysiological effects. Pilot studies also showed that $0.3 \mathrm{v} / \mathrm{v}$ of extract is the best concentration at which to evaluate the plant's effects.

Statistical analysis. Results are reported as the Mean \pm S.E., and comparisons among multiple groups were made by a two-way analysis of variance (ANOVA) with Scheffe contrasts. Comparisons between the two groups were made with the paired t test. A probability of 5\% was taken to indicate statistical significance. Non-linear curve fitting was performed with Marquardt's method by Statgraph prism 5.

\section{RESULTS}

The phytochemical analyses of Citrus aurantium essence showed that lnalool (42\%), linalyl acetate (11\%), alpha terpinyl acetate $(9 \%)$, beta terpinyl acetate $(5.5 \%)$, neryl acetate $(5.2 \%)$ and beta pinene are among the important constituents of this plant's essence. Various concentrations of $C$. aurantium increase the atrio-ventricular nodal conduction time, the effective and functional refractory period and the wenckebach cycle length (Table I). Mathematical analyses of recovery protocol, in the two concentrations used in this study, showed a non-significant increase at the time constant of recovery and a constant $b$ coefficient (Table III). We saw an upward shift in the smooth and steep part of the recovery curve with two different concentrations of $C$. aurantium (Fig. 1). These finding are due to the plant's depressant effect on both atrioventricular pathways. The behavior of this plant in changing the characteristics of nodal conduction is independent of the rate of atrial stimulation (Table III).

The results of adding varpamil at a $0.1 \mu \mathrm{mol}$ concentration show that varpamil causes a significant

Table I. The effects of different concentrations of Citrus aurantium essence on various parameters of AV-Node ( $\mathrm{n}=6$, mean $\pm \mathrm{SEM}, * \mathrm{P}<0.05, * * \mathrm{P}<0.01$ compared to the control $)$. WBCL: Wenckebach, ERP: Effective refractory period, FRP: Functional refractory period, $\Delta$ Verapamil (\%): Difference between effects of Verapamil and Citrus aurantium $(\mathrm{C}=0,3 \mathrm{ml} / \mathrm{m})$.

\begin{tabular}{llll}
\hline & WBCL $(\mathbf{m s e c})$ & FRP $(\mathbf{m s e c})$ & ERP $(\mathbf{m s e c})$ \\
\hline Control & $131 \pm 1.6$ & $147 \pm 5.1$ & $104 \pm 3.6$ \\
$0.1 \mathrm{ml} / 1$ & $135 \pm 1.7^{*}$ & $153 \pm 4.1^{*}$ & $110 \pm 6.4$ \\
$0.2 \mathrm{ml} / 1$ & $139 \pm 0.5^{* *}$ & $159 \pm 2.3^{* *}$ & $113 \pm 9.2$ \\
$0.3 \mathrm{ml} / 1$ & $147 \pm 3.9^{*}$ & $166.6 \pm 3.6^{*}$ & $112 \pm 7.6$ \\
EC50(mg/ml) & 0.2292 & 0.156 & - \\
_Verapamil $(0.1 \mu \mathrm{m})$ & $18 \%$ & $42 \%$ & $19.5 \%$ \\
\hline
\end{tabular}

Table II. The effects of different concentrations of Citrus aurantium essence on various parameters of the nodal recovery curve $(\mathrm{n}=6$, Mean $\pm \mathrm{SEM}, * \mathrm{P}<0.05$, $* * \mathrm{P}<0.01$ compared to the control $)$. AHmin:Minimum nodal conduction time, AHmax:Maximum nodal conduction time, t: time constant of recovery curve. Equation was used for non-linear, fitting :AHt=AHmin+AHmax (AA/-t).

\begin{tabular}{lccl}
\hline & AHmin $(\mathbf{m s e c})$ & AH $\max (\mathbf{m s e c})$ & $\boldsymbol{\tau}$ \\
\hline Control & $35.3 \pm 5.2$ & $81 \pm 7.2$ & $37.1 \pm 10.4$ \\
Citrus $0.2 \mathrm{ml} / 1$ & $38 \pm 4.9$ & $85.6 \pm 7.5^{*}$ & $39.2 \pm 11.3$ \\
Citrus $0.3 \mathrm{ml} / 1$ & $42.3 \pm 6.9^{*}$ & $103 \pm 3.5^{*}$ & $45.2 \pm 8.4$ \\
Ouabain $(0.1 \mu$ molar $)$ & $51 \pm 11.5^{*}$ & $125.6 \pm 13.9^{* *}$ & $49.8 \pm 6.08^{*}$ \\
\hline
\end{tabular}



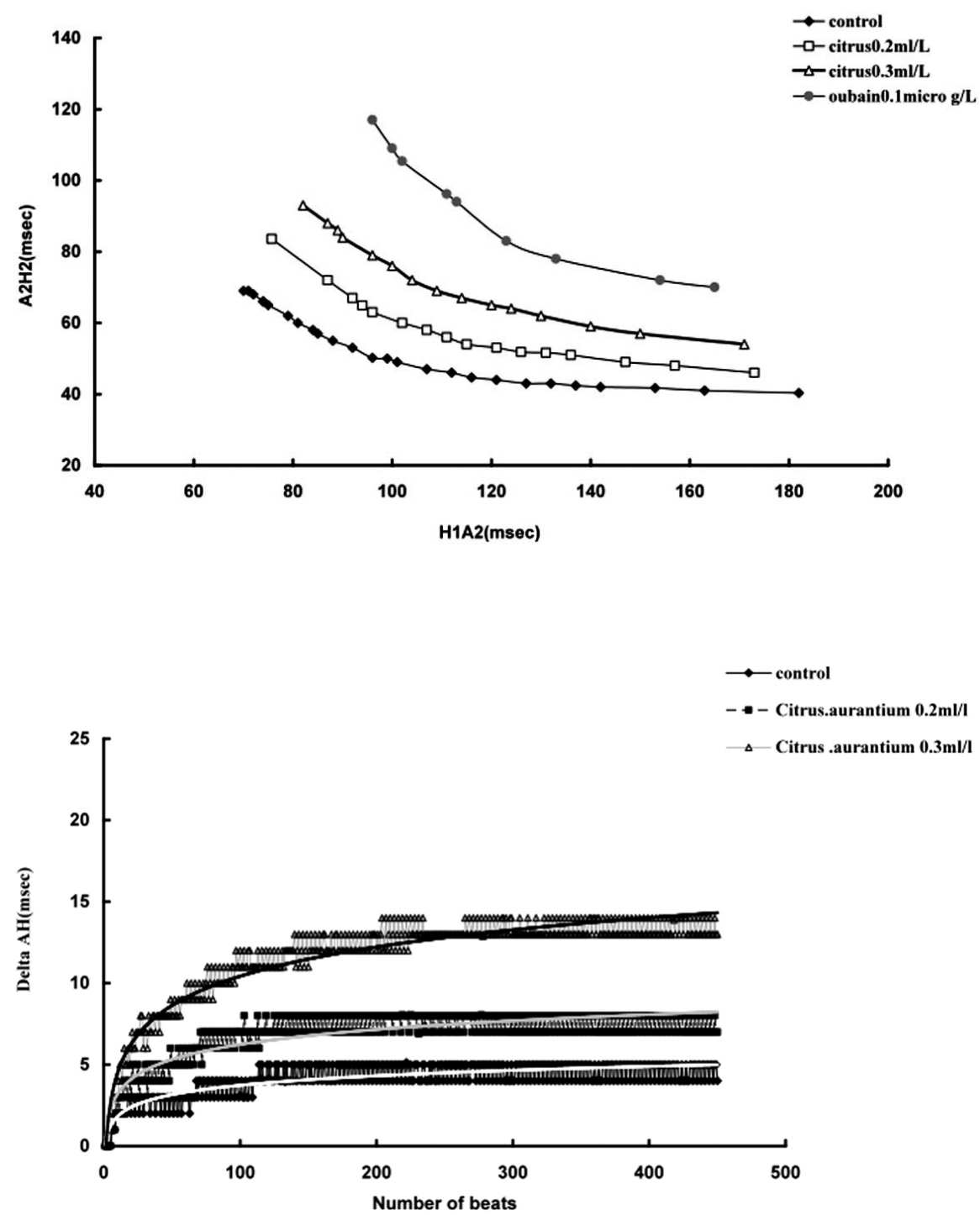

Fig. 1. The effects of different concentrations of Citrus aurantium essence on the nodal recovery curve. There is a concentration-dependent upward shift of the recovery curve. Ouabain has a greater effect than the plant on the recovery curve.

Fig. 2. The effects of different concentrations of Citrus aurantium essence on the nodal fatigue curve. There is a concentration-dependent upward shift of the fatigue curve. increase in the nodal conduction time, effective and functional refractory period and wenchebach. Citrus aurantium in a concentration-dependent model can cause a considerable inhibitory effect compared to verapamil. As an example, the depressant effect of essence of $C$. aurantium at a concentration of $0.3 \mathrm{v} / \mathrm{v}$ is $32 \%$ of verapamil's effect on the atrio-ventricular nodal conduction time.

Citrus aurantium essence's effect on nodal conduction and on the refractory period is concentrationdependent, similar to verapamil. In a separate set of experiments, $(n=6)$, ouabain $(0.1 \mu$ molar $)$ caused time- and concentration-dependant depression of nodal conduction and refractory period (Table II). A separate set of experiments studied the effect of C. aurantium in the presence of ouabain (0.1 $\mu$ molar). Those results showed a significant increase in the wenckenbach and effective refractory period indices, and an insignificant increase in the nodal conduction time and functional refractory period, compared to ouabain alone (Table II).

The results of different concentrations of $\mathrm{C}$. aurantium indicated that the index of facilitation (DAV-FRP) increased by $7.5 \pm 0.9 \mathrm{msec}$ at $0.3 \mathrm{v} / \mathrm{v}$ and with the same concentration, the magnitude of fatigue increased by $6.5 \pm$ $0.5 \mathrm{msec}(\mathrm{p}<0.05)$. 
KHORI, V.; NAYEBPOUR, M.; MANSOURIAN, A. R.; DAVARIAN, A.; NASERI, M.; SALEHI, A. \& ALIZADEH, A-M. Altered levels of nodal excitability by rate-dependent inhibitory effects of essential oil of Citrus aurantium on the electrophysiological properties of isolated perfused rabbit AV-Node. Protective role in the prevention of Ouabain toxicity. Int. J. Morphol., 28(2):445-451, 2010.

Table III. A comparison of Citrus aurantium's (Citrus.a) and ouabain's effects on the basic nodal parameters $(\mathrm{n}=6$, mean $\pm \mathrm{SEM}, * \mathrm{P}<0.05$, $* * \mathrm{P}<0.01$ compared to the control, $\# \mathrm{P}<0.05$ compared to the DOUA-Citrus.a). WBCL: Wenckebach, ERP: Effective refractory period, FRP: Functional refractory period, OUA+Citrus.a: The effects of Citrus aurantium in the presence of ouabain. DOUA-Citrus. a: The difference between the effects of Citrus aurantium and ouabain. DOUA: The difference between ouabain's $(0.1 \mu \mathrm{M})$ effects and the control (in the absence of Citrus aurantium).

\begin{tabular}{lcccc}
\hline & AH $(\mathbf{m s e c})$ & WBCL $(\mathbf{m s e c})$ & ERP $(\mathbf{m s e c})$ & F RP $(\mathbf{m s e c})$ \\
\hline Control & $32.6 \pm 3.9$ & $131.7 \pm 1.6$ & $104.3 \pm 3.6$ & $147 \pm 5.1$ \\
Citrus. a $(0.3 \mathrm{ml} / \mathrm{l})$ & $40 \pm 6.1^{*}$ & $147 \pm 3.9^{*}$ & $112.7 \pm 7.6$ & $166.6 \pm 3.6^{*}$ \\
OUA+Citrus. a & $46 \pm 10.2^{*}$ & $154.3 \pm 5.3^{* *}$ & $124.6 \pm 18.6^{*}$ & $179.6 \pm 13.3^{* *}$ \\
_OUA-Citrus. a & 6 & 7.3 & 12 & 13 \\
_OUA & 7.1 & $20.7^{\#}$ & $16.2^{\#}$ & 12.3 \\
\hline
\end{tabular}

\section{DISCUSSION}

The results of this investigation showed that the essential oil of $C$. aurantium, in a time-and concentrationdependant manner and a rate-independent model (meaning that the effect of $C$. aurantium doesn't increase with an increasing rate of atrial stimulation), caused the depression of nodal properties. Recent studies indicate that the conduction curve of the atriventricular node consisted of two separate sections. When nodal function is represented with a recovery curve (premature Atrial-His interval vs. cycle length), a fast pathway (based on a compact node) accounts for atrial-His intervals observed at long and intermediate cycle lengths. During anterograde conduction, the premature impulses travel fast and slow pathways in the flat and steep rising portions of the nodal curve, respectively (Reid et al., 2003).

The increase in the minimum conduction time caused by $C$. aurantium. reflects the plant's effect on the fast pathway (the transitional cells of the compact node's anterior section). On the other hand, the increase in the maximum conduction time (AH max) and FRP explain this plant's ratedependent anti-arrhythemic effect on the compact node. The rate-independent effect of $\mathrm{C}$. aurantium can be understood from the insignificant increase in the recovery time-constant.

In any case, the recovery curve's upward transition in a concentration-dependent model, indicates $C$. aurantium's effectiveness on both the slow and fast nodal pathways. The comparison between the different concentrations of $\mathrm{C}$. aurantium indicates that this essence does not have as much efficacy as verapamile $(0.1 \mu$ molar $)$ on the electrophysiologic parameters of the atrioventricular node. Ouabain in a $0.1 \mu$ molar concentration increased the basic and rate-dependent nodal parameters.
Citrus aurantium did inhibit ouabain's effect on the wechenbach cycle's length and the effective refractory period, which indicated $C$. aurantium's effects on the slow and fast pathways. Citrus aurantium reduced ouabain's depressant effect on the atriorentricular node. Ouabain can inhibit the Na+-K+ pump (Glitsch, 2001), and C. aurantium's prevention of ouabain's effect can explain $C$. aurantium's similar mechanism on the same site of the Na+-K+pump.

Previous studies showed C. aurantium's inhibitory effect on the $\mathrm{Na}+\mathrm{K}+-$ ATPase pump (Umarova et al.; Hirano et al.); therefore, it can be assumed that $C$. aurantium's depressant nodal effects may probably act through the inhibition of the $\mathrm{Na}+/ \mathrm{K}+-$ ATPase pump. The $\mathrm{Na}+/ \mathrm{K}+-$ ATPase pump's inhibition can be considered a probable mechanism of fatigue, so this plant can increase fatigue by inhibiting this pump. In the fatigue protocol the tissue is stimulated by various stimuli similar to supraventricular tachyarrhythmia. On the other hand the fatigue is explained due to the compact node cells' long refractory period (Billette $\&$ Shrier, 1995). The increase in the fatigue index caused by $C$. aurantium reflects the plant's role in decreasing the distal node's excitability and increasing the artrioventricular node's protective role; therefore, C. aurantium's effect on fatigue represents the plant's potential role in preventing arrhythmia. The node's mechanism of refractoriness is still unknown (Billette \& Shrier). The increase in the functional refractory period and the wenchenbach cycle's length explain $C$. aurantium's definite effect on the distal nodal cells in the compact node. The previous studies explain that proximal nodes' transitional cells play a role in the facilitation mechanism (Mazgalev et al., 1997). It is possible that $C$. auranium affects the proximal part of the node. 
KHORI, V.; NAYEBPOUR, M.; MANSOURIAN, A. R.; DAVARIAN, A.; NASERI, M.; SALEHI, A. \& ALIZADEH, A-M. Altered levels of nodal excitability by rate-dependent inhibitory effects of essential oil of Citrus aurantium on the electrophysiological properties of isolated perfused rabbit AV-Node. Protective role in the prevention of Ouabain toxicity. Int. J. Morphol., 28(2):445-451, 2010.

The insignificant increase in the effective refractory period expresses $C$. aurantium's relative efficacy on the atrioventricular node's slow pathway, which is indicative of the plant's reduced effect on the protective mechanism located in the proximal part of the posterior atriventricular node. On the other hand, the increase in the WBCL as a determinant of the atrioventricular node's functional refractory period indicates $C$. aurantium's protective role in preventing supraventricular tachyarrhythmia. Citrus aurantium's similar and widespeared depressant effects on the AV node's common transitional pathway, which is manifested as an upward shift in the conduction curve, and the insignificant change in constant recovery time, at least to some extent indicate this plant's pro-arrhythmic effect. These findings agree with the results of Zitron et al. (2005), which showed the high efficacy of flavonoids in grapefruits in blocking HERG ionic channels; therefore, we are suggesting $C$. aurantium's potential proarrythemic role in patients with heart disease.
The $C$. aurantium in the concentration-dependant and rate-independent model caused depression of nodal conduction and refractoriness, which the plant's effect pronounced on the fast pathway rather than the slow one. Citrus Aurantium's inhibitory effects on nodal cells is comparable, to some degree, to verapamil's. Citrus aurantium probably protects against ouabaein toxicity. Further investigation recording the technique through ionic channels and intracellular recording is required to determine much more accurately the mechanism of $C$. aurantium on atrioventricular nodal cells.

\section{ACKNOWLEDGMENT}

This research was financially supported by the research deputy of Golestan University of Medical Sciences. Also, the authors thank Dr.Solimani for providing the Citrus aurantium essence.

KHORI, V.; NAYEBPOUR, M.; MANSOURIAN, A. R.; DAVARIAN, A.; NASERI, M.; SALEHI, A. \& ALIZADEH, A-M. Alteración de los niveles de excitabilidad nodal por efectos inhibitorios velocidad-dependiente del aceite esencial de Citrus aurantium sobre las propiedades electrofisiológicas del nodo AV aislado y perfundido de conejo. Papel protector en la prevención de toxicidad por Ouabaína. Int. J. Morphol., 28(2):445-451, 2010.

RESUMEN: El tratamiento de la arritmia supraventricular incluye una amplia gama de intervenciones médicas. Los remedios herbarios son alternativas adecuadas a las drogas sintéticas debido a su disponibilidad, con escasos efectos secundarios y bajo precio. Estudios farmacológicos y la literatura médica tradicional señalan los efectos cardiovasculares de Citrus aurantium L. (Rutaceae) en muchos casos. En el presente estudio se usaron aislados perfundidos del nodo AV de conejo como modelo experimental para determinar el efecto de diferentes concentraciones de aceite esencial de $C$. aurantium (0,1-0,3 v/v) sobre en el tiempo de conducción nodal y refractariedad. Un protocolo de estimulación selectiva se utilizó para cuantificar de forma independiente la recuperación, la facilitación y la fatiga del nodo AV en 18 conejos. Nuestros resultados muestran efectos supresores dependientes de la concentración e independiente de la velocidad de la esencia de $C$. aurantium sobre la duración del ciclo Wenchebach (WBCL), tiempo de conducción AV (AVTC) y períodos refractarios eficaz y funcional (PRE y PRF). Propiedades funcionales tales como la facilitación y la fatiga se incrementaron de manera significativa por esta planta. La Citrus aurantium juega un papel protector contra los efectos tóxicos de ouabaína al incrementar el tiempo de conducción AV nodal y la refractariedad. Los resultados indican efectos diferenciales de $C$. aurantium sobre las vías lentas y rápidas, con un papel dominante en las vías rápidas. Esta investigación ha explicado el papel protector de C. aurantium sobre la toxicidad ouabaine. Todos los resultados indican los posibles efectos anti-arrítmicos de $C$. aurantium en el tratamiento de taquiarritmias supraventriculares.

PALABRAS CLAVE: Citrus aurantium; Nodo AV aislado; Arritmia; Drogas herbales.

\section{REFERENCES}

Billette, J. \& Shrier, A. Atrioventricular nodal activation and functional properties. In: Zipes, D. P. \& Jalife, J. (Eds). Cardiac Electrophysiology: From Cell to Bedside. Philadelphia, WB Saunders, 1995. pp.216-28.

Fleming, T. PDR for herbal medicines. $2^{\text {nd }}$ Ed. Montvale, NJ, Medical Economics Company, 2001. pp.86-7.
Guerra, P. G.; Talajic, M.; Roy, D.; Dubuc, M.; Thibault, B. $\&$ Nattel, S. Is there a future for antiarrhythmic drug therapy? Drugs, 56(5):767-81, 1998.

Glitsch, H. G. Electrophysiology of the sodium-potassiumATPase in cardiac cells. Physiol. Rev., 81(4):1791-826, 2001. 
KHORI, V.; NAYEBPOUR, M.; MANSOURIAN,A. R.; DAVARIAN, A.; NASERI, M.; SALEHI,A. \& ALIZADEH, A-M. Altered levels of nodal excitability by rate-dependent inhibitory effects of essential oil of Citrus aurantium on the electrophysiological properties of isolated perfused rabbit AV-Node. Protective role in the prevention of Ouabain toxicity. Int. J. Morphol., 28(2):445-451, 2010.

Hirano, T.; Oka, K. \& Akiba, M. Effects of synthetic and naturally occurring flavonoids on $\mathrm{Na}+\mathrm{K}+$-ATPase: aspects of the structure-activity relationship and action mechanism. Life Sci., 45(12):1111-7, 1989.

Itoigawa, M.; Takeya, K.; Ito, C. \& Furukawa, H. Structureactivity relationship of cardiotonic flavonoids in guineapig papillary muscle. J. Ethnopharmacol., 65(3):267$72,1999$.

Joshi, S. G. Medicinal plant. $1^{\text {st }}$ Ed. New Dehli, Oxford \& IBH Pub. Co. Pvt. Ltd., 2003. pp.342-3.

Lewis, T.; Drury, A. N. \& Wedd, A. M. Observations upon the action of certain drugs upon fibrillation of the auricles. Heart, 9:207-67, 1922.

Mazgalev, T.; Mowrey, K.; Efimov, I.; Fahy, G. J.; Van Wagoner, D.; Cheng, Y. \& Tchou, P. J. Mechanism of atrioventricular nodal facilitation in rabbit heart: role of proximal AV node. Am. J. Physiol., 273(4 Pt 2):H1658$68,1997$.

Nayebpour, M.; Naseri, M. \& Khori, V. Effects of ajmaline on rate-dependent atrioventricular node properties. Potential role in experimental atrioventricular re-entrant tachycardia. Eur. J. Pharmacol., 412(1):77-89, 2001.

Reid, M. C.; Billette, J.; Khalife, K. \& Tadros, R. Role of compact node and posterior extension in direction-dependent changes in atrioventricular nodal function in rabbit. J. Cardiovasc. Electrophysiol., 14(12):1342-50, 2003.

Shoshan, V. \& MacLennan, D. H. Quercetin interaction with the $(\mathrm{Ca} 2++\mathrm{Mg} 2+)$-ATPase of sarcoplasmic reticulum. J. Biol. Chem., 256(2):887-92, 1981.

Takeya, K.; Itoigawa, M. \& Furukawa, H. Triphasic inotropic response of guinea-pig papillary muscle to murrayaquinone-A isolated from Rutaceae. Eur. J. Pharmacol., 169(1):137-45, 1989.

Umarova, F. T.; Khushbactova, Z. A.; Batirov, E. H. \& Mekler, V. M. Inhibition of $\mathrm{Na}+\mathrm{K}(+)$-ATPase by flavonoids and their inotropic effect. Investigation of the structure-activity relationship. Membr. Cell Biol., 12(1):27-40, 1998

Wu, J.; Yu, X. J.; Ma, X.; Li, X. G. \& Liu, D. Electrophysiologic effects of total flavones of Hippophae rhamnoides L on guinea pig papillary muscles and cultured rat myocardial cells. Zhongguo Yao Li Хие Bao, 15(4):341-3, 1994.
Zitron, E.; Scholz, E.; Owen, R. W.; Lück, S.; Kiesecker, C.; Thomas, D.; Kathöfer, S.; Niroomand, F.; Kiehn, J.; Kreye, V. A.; Katus, H. A.; Schoels, W. \& Karle, C. A. QTc prolongation by grapefruit juice and its potential pharmacological basis: HERG channel blockade by flavonoids. Circulation, 111(7):835-8, 2005.

\section{Correspondence to: \\ Aref Salehi \\ Department of Cardiology \\ Golestan cardiovascular research center \\ Golestan University of Medical Sciences \\ Gorgan \\ IRAN}

Tel:+981714421651-4422652

Fax:+98 1714421289.

Email: Vaph99@yahoo.com

Received: 31-10-2009

Accepted: 03-03-2010 
